\title{
Central Banking and Monetary Management in Islamic Financial Environment
}

\author{
Muhammad Nadim Hanif \\ Salman Ahmed Shaikh
}

\begin{abstract}
Continuous growth in Islamic finance calls for an in-depth study of the framework in which the monetary policy maker (i.e., the central bank) performs its functions. Central banks in Muslim countries are using various instruments for monetary policy purpose including interest rate. As a result, Islamic Financial Institutions (IFIs) are facing issues in benchmarking the price of financial instruments. Acceptable solution to benchmarking lies in the presence of a real economic activity in the base of any proposal and its feasibility for business performance when put against conventional banking. This paper presents empirical evidence of statistical equivalence of nominal GDP growth rate and official interest rate for 'advanced,' 'all,' and some Muslim countries. We propose nominal GDP growth rate as benchmark for pricing domestic financial transactions of IFls as well as for pricing external bilateral/multilateral loans. The paper also suggests nominal income targeting as monetary policy regime and provides a liquidity management mechanism for banking system in Islamic financial environment.
\end{abstract}

Keywords: Islamic finance, central bank, interest rate, nominal income targeting, Liquidity Management.

\section{Introduction}

Islamic finance has grown strong particularly during the last 50 years in various parts of the world including Bahrain, Egypt, Indonesia, Malaysia, Pakistan, Sudan to name but few and in some non Muslim countries (like China, UK). However, little attention has been paid to the framework in which the monetary policy maker and conductor (i.e., the central bank) performs its functions. Resultantly, despite tremendous growth in Islamic financial services, Islamic financial institutions are faced with issues that prove hurdles in their functioning to their own satisfaction and to the satisfaction of their customers. One such hurdle is the non-availability of acceptable benchmark price for Islamic financial instruments. It is currently linked to the price of conventional instruments (like KIBOR in the case of Pakistan). This paper reviews available literature on central banking in Islamic financial environment and the practice followed by central banks for liquidity management and monetary management in countries where Islamic banking is prevalent. With the help of easily available data and based on a simple statistical test, the paper proposes a benchmark for pricing domestic financial transactions as well as international bilateral/multilateral and institutional arrangements like with IMF and World Bank. It also suggests a monetary policy regime for central banks compliant with Islamic principles.

Muhammad Nadim Hanif is Senior Economist, Research Department, State Bank of Pakistan, muhammadnadeemhanif@yahoo.com

Salman Ahmed Shaikh is lecturer at University of East, Hyderabad, salmanahmed_hyd@hotmail.com

Research assistance provided by Javaid lqbal and Amjad Ali is acknowledged. Views expressed are of the authors and not their employers. 


\section{Literature Review}

In literature, relevant to the role and functions of central bank and monetary management based on Islamic ideas, we find concepts such as refinance ratio (Siddique, 1982), qard-e-hasnah ratio (Khan, 1982), Mudarabah based lending between commercial and central banks and restricting high powered money by way of required reserve ratio than relying on OMO (Chapra, 1983), composite stock (Zangeneh \& Salam, 1993) and central bank having equity stake in commercial banks (Uzair, 1982) to name a few. None has challenged the monetary policy regime within which central banks operate to purify the central bank from use of interest rate. As a result, central banks in Muslim countries are following interest related monetary policy regimes and Islamic commercial banks have been facing problem pertaining to benchmark price; like price of Islamic financial instruments in Pakistan are linked to KIBOR (Karachi Interbank Offered Rate) which is basically a pricing benchmark for conventional banking.

Kurrihara (1951) asserts that if a central bank is the government's bank, then, if government sells securities to the central bank, interest paid by the government will eventually come back to the government without economic or payoff difference. A number of Shariah scholars hold this view. But to some scholars interest is prohibited in absolute sense and it cannot be accommodated even if the same transaction is reversed over a period of time and thereby nullifying the economic impact. Furthermore, during the financial repression, governments around the world had been manipulating remuneration in favor of fiscal authorities while selling securities to central banks. To do so has always been easy for governments because they have not to record (with central banks) economic activities for such transactions.

Chapra (1983) realizing that the two important instruments of monetary policy in the capitalist economy, discount rate and $\mathrm{OMO}$ in interest-bearing government securities will not be available, recommended following measures:

- central bank should make the reserve money, created by it, available partly to the government and partly to the commercial banks and the specialized financial institutions;

- a proportion of commercial banks' demand deposits (say 25 per cent) should be diverted to the government to enable it to finance socially beneficial projects in which profitsharing is not feasible and the government would pay service charges to the commercial banks for their deposit mobilization services;

- commercial banks should be required to hold a certain proportion (say 10-20 per cent) of their time and demand liabilities with the central bank as statutory reserves and the central bank should pay the commercial banks the cost of mobilizing these deposits just as the government would pay the cost of mobilizing demand deposits diverted to the government.

Siddiqui (1982) supported the use of refinance ratio, i.e., central bank refinancing a part of the interest-free loans provided by commercial banks to influence the volume of short-term credit extended by commercial banks.

Khan (1982) advocated the use of qard-e-hasnah ratio, i.e., the percentage of demand deposits that commercial banks are obliged to lend as interest free loan to influence the availability of credit.

Uzair (1982) proposed that a central bank can acquire equity stake in commercial banking by holding 25 per cent of the capital stocks of the commercial banks to get a permanent source of income and play its role as a lender of last resort. However, his proposal can cause conflict of interest between regulator and private banking institutions.

Along with other suggestions, Zangeneh and Ahmad (1993) presented an alternative to money management. They recommended that the central bank could charge the borrowing bank a weighted average rate of return in different sectors of the economy. This will create problems with 
reference to choice of sectors to calculate the weighted average rate of return. A particular bank may not have any investment in certain sector(s). Furthermore, this suggestion does not solve all the problems pertaining to pricing of products in Islamic finance. Reddy (2001) highlighted an important problem in an Islamic economy as to how it will deal with external debt management which is primarily interest based.

Khan (2004) argued against elimination of interest by a legal decree and favored free market forces to bring the interest rates down to zero. To him by doing so no one will be saving (for lending purpose) rather will be using saved money for equity share holding.

He emphasized on providing incentives for the use of equity over debt financing. He proposed following policy measures:

- reducing reserve requirements to increase supply of loanable funds;

- enforcing unlimited liability;

- gradual decline in interest to make investments in debt based instruments less lucrative and shift loanable funds towards equity based instruments;

- allowing dividend as a tax deductible expense; and

- providing fiscal incentives to non-leveraged firms and disincentives to leveraged firms.

\section{Existing Practices in Muslim Countries}

In almost all the Muslim countries a combination of various policy instruments are used for monetary policy purpose including:

a) Minimum Reserve Requirement;

b) Open Market Operations, and

c) Discount Rate.

The case in point is the monetary policy of Saudi Monetary Agency (SAMA) which relies primarily on variations in the reserve ratio requirements. A significant secondary tool is selective credit controls which include regulation of credit ceilings, cash margins, terms and conditions of customer transactions, limits, prohibitions on specific categories of loans, and fixing the assets to be held within the Kingdom by each bank. SAMA also uses its own accounts and government deposits with commercial banks to regulate the money supply. But again SAMA uses ORR (Official Repo Rate) for short-term liquidity management.

In some countries there are some special arrangements for Islamic financial transactions. Such countries include Sudan and Malaysia. Central bank of Sudan provides financial support to the Islamic banks facing liquidity problems through purchasing financial papers Sukuks from them. In Malaysia, various types of instruments are in use including Bank Negara Monetary Notes-i (BNMN-i). Malaysia has sophisticated array of Islamic finance products. However, the prevalent use of Bai-al-Dayn (Sale of Debt) and Bai-Inaah (Buy Back) is not recommended by many Islamic scholars and hence it warrants us to look for better alternatives compliant with Islamic principles.

Operational side of monetary management is relatively better developed in countries like Pakistan and Malaysia. In Pakistan two interbank trading agreements-the Interbank Musharakah and Interbank Wakalah-are being used as standard contracts in the Islamic finance industry. The Islamic interbank market is in the process to replace the KIBOR, with the Islamic Interbank Offered Rate (IIBOR), and offer an avenue for Islamic banks to lend excess funds to each other. (Although it is feared that conceptually it will not be much different from KIBOR.) Interbank 
Musharakah is a short term restricted partnership where the banks are invited to invest amount in a special pool of assets on a pre-agreed profit sharing ratio agreed upon at the outset.

Interbank Wakalah is an investment management contract whereby the investor agrees to provide the Islamic bank with funds to invest in different assets. The Islamic bank acts as the investor's agent and is paid a service based fee. In Malaysia, the Islamic Inter bank Money Market (IIMM) was introduced in 1990s as a short-term intermediary to provide a ready source of short-term investment outlets based on Shariah principles. Through the IIMM, the Islamic banks and banks participating in the Islamic Banking Scheme (IBS) match the funding requirements effectively and efficiently.

Some of the alternatives relevant to money market and liquidity needs established and used in Islamic banking includes: a) Bai Salam in Bill Discounting; b) Running Musharakah; c) Tijara for Short Term Liquidity Management; d) Treasury Financing by way of Short Term Investment through Pool Management; e) Treasury Investments by way of Short Term Investment through Commodity Murabaha; f) Shariah Compliant Asset Backed Securitization like Sukuks. But benchmarking the return is crucial issue in most of the cases to get approval from Shariah Boards.

\section{Benchmark Price for the Islamic Financial Instruments}

Solution to the benchmarking the price of Islamic financial instruments rests in the presence of real economic activity in the base of any proposal and its feasibility for business performance in the presence of conventional banking. To find such a solution the paper marries two ideas: one found in Islamic economics literature where Usmani (2003) referred to the proposal of linking extra remuneration of instruments of public finance to the GDP growth rate and other found in contemporary economic wisdom where we see gap between nominal GDP growth rate and official interest rate as the monetary policy stance (Economist, 2007). [The Economist (2007) has used a figure showing the gap between nominal GDP growth and official interest rate of big economies (America, Britain, Canada, China, the euro area, India and Japan) for period 1970 to 2007 (and forecasts for 2008) as an indicator of monetary policy stance. The decline (rise) in positive gaps shows tight (loose) monetary policy.]

Following Economist (2007), we have shown in figure 1 that (average) official interest rate and (average) nominal GDP growth rate moves along based on available data for Canada, 16 major Euro area countries, Japan, US, and UK for 1970-2008. (These account for 64 per cent of world GDP.)

Figure 1: Advanced countries offical interest rate and Nominal GDP growth rate

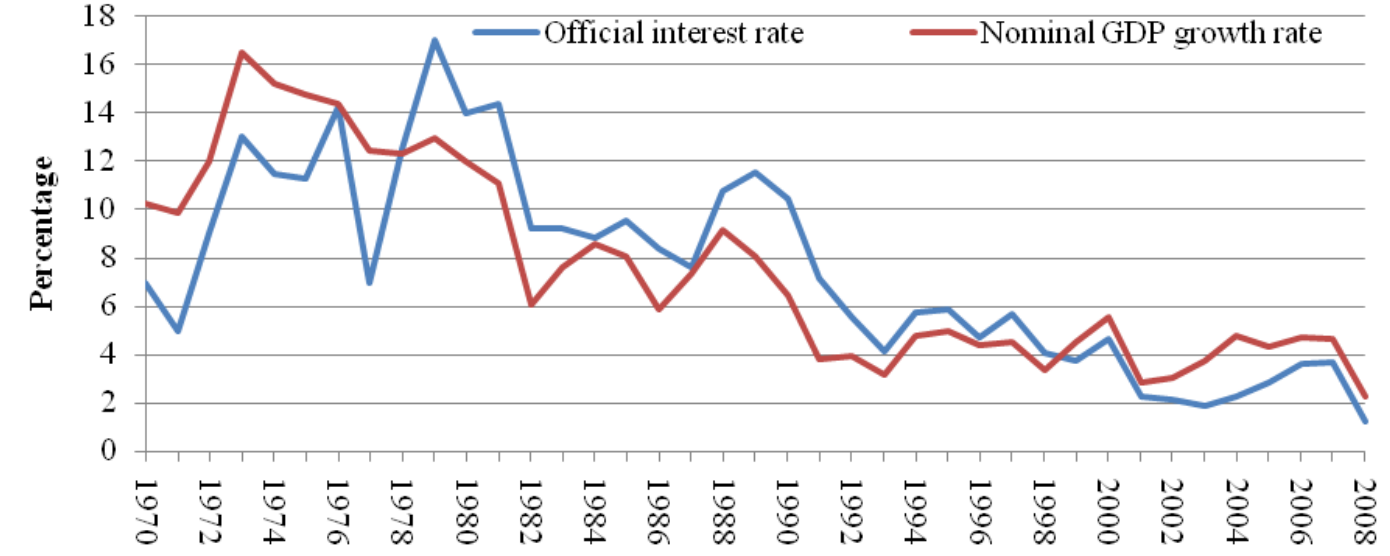

Source: Haver Analytics 
Is this phenomenon true only for advanced countries? Not all countries use similar type of policy rates. There can be different monetary policy regimes in different countries. From the latest available International Financial Statistics of International Monetary Fund (IMF), we have collected nominal GDP growth rate and official policy (interest) rate. We find only 125 such countries for which consistent data series were available for both the variables. Based upon the standard deviation of the nominal income growth series (for each country) we dropped the top 20 per cent highly volatile countries and plotted in figure 2 the average official interest rate and nominal GDP growth rate of remaining 100 countries (for list see Table 2 of Appendix) for 19812008. The behavior of the two variables for a larger set of countries is not different from those of advanced economies shown in figure 1.

Figure 2: 100 countries offcial inter est rate and nominal GDP growth

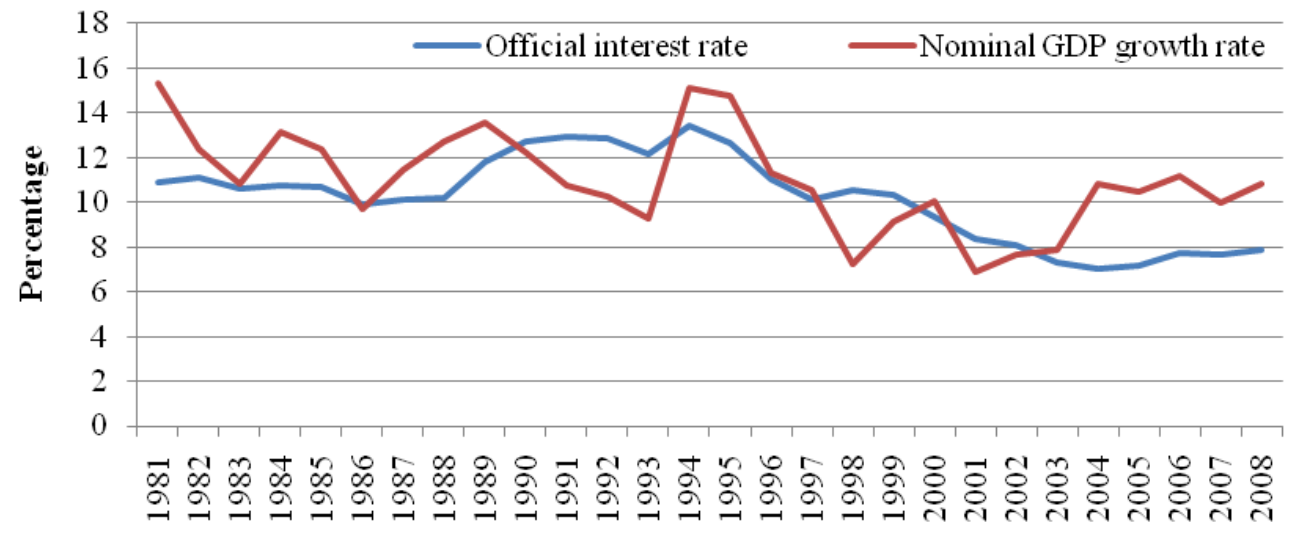

Source: International Financial Statistics of IMF

In addition to the above visual analysis the study has also tested if the means of these two series are statistically equal. Table 1, has the results of the test of equality of means of these two series. For advance countries group (Canada, 16 major Euro area countries, Japan, US, and UK), for 100 countries group, and a set of Muslim countries (Bahrain, Indonesia, Jordan, Kuwait, Oman, Saudi Arabia, Sudan and Yemen), the null hypothesis could not be rejected as the means of nominal income growth and official policy interest rate are equal except in the case of Bangladesh, Egypt, Malaysia and Pakistan. Selection of those Muslim countries for analysis where Islamic finance practices are more prevalent was deliberate. Looking at the graph above and the results of the test conducted we propose (expected) annual NGDPGR (announced by central government body like planning commission) to be used as benchmark for Islamic finance products of assets side. [For the two groups of countries ('advanced' as well as 'all' 100 for those relevant consistent data series were available) we have also tested and found variances of the official policy rate and nominal GDP growth rate to be statistically same. This strengthens our suggestion that Nominal GDP growth rate can be used as benchmark for pricing of Islamic financial instruments as the data on nominal income growth rate and official policy rate are statistically found to be generated from the distributions with same mean and variance.]

Products on liabilities side can be priced based upon the difference between NGDPGR and the cost of deposit mobilization. For the purpose of saving depositors from deprivation of minimum returns central banks can come up with some regulatory measures. One such example could be to ensure that IFIs pay at least half of the expected nominal GDP growth rate as remunerations to depositors. This will keep spread in check and force IFIs to keep their expenses reasonable. Nominal GDP and interest rate are conceptually different in the sense that following the later is haram and the former is not forbidden.

At present in most of the countries quarterly (year on year) growth in GDP is released by the relevant statistical agencies. Monthly release of such figures is a demanding task and only 
projections are available and that, too, not for all countries. Countries where such figures are released less frequently (like Pakistan) things are heading right. An important question arises with reference to yield curve (relation between return and time to maturity of contract). For short period of time the rates can be settled on the basis of projections for monthly NGDPGR, expected quarterly NGDPGR and expected annual NGDPGR announced by the government body. For longer periods than one year contracts can be based upon projected NGDPGR in governments' medium to long term plans and accounts can be settled/reconciled later on the basis of realized NGDPGR of the economy. (Slope of the yield curve itself is based upon expected future economic performance. So it is better to link price of the financial instruments directly to the future expected nominal income growth rate.)

Is benchmarking Islamic financial instrument to NGDPGR superior to conventional measure of monetary policy stance? Yes. To understand this, a visit to the literature in monetary economics is must. If the gap between nominal GDP growth rate and interest rate is a monetary policy stance then the proposal makes the nominal GDP growth rate a policy stance and thus policy remains neutral-neither tight nor loose. (Real GDP growth rates turn negative during recession but this is rare for nominal GDP growth rate. But still one can ask what to do when nominal GDP growth is going to be negative. The suggestion is to benchmark the pricing of Islamic financial instruments to zero for assets side. On the liabilities side Islamic financial institutions can ask for service charges from the deposit holder as has been suggested in the literature while discussing deflation management in late 1990s in Japan.)

Central banks in Islamic countries can use nominal income targeting as monetary policy regime. (Though issues pertaining to nominal income targeting as monetary policy regime in Islamic countries can be addressed in a different research study which is out of scope of this paper but nominal income targeting will also be useful in balancing the role of central bank as conservative one and as pro- growth.)

Furthermore, it gives incentive to lender to oversee the use of lent money to ensure proposed use of money in effective manner to raise the returns to economy and to itself.

Another question that can be asked in this regard, 'is it similar to indexation to inflation?' The answer is no. Inflation is subjective measure compared to income growth rates. Our proposal includes real income factor in addition to the inflation (compensation).

An important aspect of the proposal in this study is that it can be used in solving issues in external debt management of countries ready to operate their economies on Islamic economics principles even if the lending/borrowing country/institution is operating under capitalistic structure. Take example of International Monetary Fund (IMF). IMF provides lending to member countries for dealing with balance of payments crisis and to maintain stability in the economy in the form of Stand-By Arrangements (SBA), Flexible Credit Line (FCL), Emergency Assistance (EA), Exogenous Shocks Facility (ESF) and Poverty Reduction and Growth Facility (PRGF) etc. If these loans are in IMF's reserve currency, i.e., SDR which is composed of a basket of currencies namely USD, JPY, GBP and Euro; the financing facility so provided can be benchmarked using nominal GDP growth rate of the lender's country of origin or benchmarked with weighted nominal GDP growth rate in major donor countries.

The weight of the member countries' currencies in SDR can be used as weights for calculating the weighted average nominal income growth. This is an example and various kinds of international transactions can be benchmarked in this manner. A better way is to link with the nominal income growth in recipient country. On the one hand, it may involve issues pertaining to convincing the lender; on the other hand, it will create a corporate management reason to oversee the loan utilization by the recipient for intended use with better performance of recipient economy. In this case there are also issues pertaining to the currency in which transaction is going to be negotiated. 
Similarly, financing in development projects from World Bank and International Development Association (IDA) can also be benchmarked with weighted Nominal GDP growth rate in major donor countries. This will be an alternative for interest based financing. For soft loans the nominal GDP growth rate in the recipient country can be linked (like at the rate of one-fourth of nominal GDP growth rate).

\section{Monetary Management in Islamic Financial Environment}

Central banks in countries with Islamic financial environment should follow nominal income targeting as policy regime by characterizing monetary policy as nominal income growth reaction function. Nominal income growth is to respond with differing intensity to deviation of inflation from target inflation and to deviation of real output gap from zero. We proposed above (expected) annual NGDPGR to be used as benchmark for Islamic finance products of assets side and NGDPGR less cost of deposit mobilization to be used as benchmark for products on liabilities side. In between these two rates have to be the rate (like $90 \%$ of expected nominal income growth rate) at which banks should be able to place their surplus funds and one such area is financing the government deficits.

When it comes to financing government deficit this should only be for public sector development projects approved by a (government) Shariah Body, like Islamic Ideology council in Pakistan, that these projects will be used for permitted (by Islam) economic activities (ensuring no other conventional financing is mixed in such projects). In case government is not in need of funds and IFIs has surplus funds to place, central bank should suck such funds (at the rate at which government should have taken the funds in case of her needs). At the time of needs of liquidity IFIs should be able to utilize central bank's windows to borrow money at expected nominal income growth rate for short term. In case government is in need of financing Shariah approved projects, and there is no surplus funds with IFIs, central bank should decide to fully/partially finance (at the rate at which IFIs should have financed in case they had surplus funds) the project(s) depending upon overall monetary (policy) management in the country in the light of nominal income growth reaction function.

\section{Conclusion and Recommendations}

There has been a rapid growth in the Islamic financial transactions, particularly during the recent past. Parallel to this growth some efforts have been made to devise a mechanism for managing liquidity in Islamic financial market. However, little attention has been paid to the issue of establishing a benchmark for pricing Islamic financial instruments. This non-existence of a distinct and standardized benchmark has created obstacles in the creation and growth of more preferable Islamic alternatives. Central banks in countries where Islamic finance is growing are using interest rate as major policy instrument. So the need is not only to think of an acceptable benchmark (to Shariah scholars and practicable in the presence of competition from conventional financial instruments in the market) for pricing the Islamic financial instruments but also to look into policy regime under which central banks are operating. Combining the two ideas, one from conventional economics and other from Islamic economics literature, this study contributes in proposing a benchmark for Islamic finance industry usable for pricing Islamic finance products and in pricing instruments for public finance, the trading in which will create a source of public finance by replacing conventional OMO through providing a base instrument in OMO in Islamic monetary framework. Based on a simple visual and statistical exercise, we suggest that nominal income growth rate can be used as benchmark for pricing Islamic financial instrument.

For conventional economist, it is an indicator which moves almost together with the conventional official policy rate. For Shariah scholars in Islamic finance, it is based upon actual economic activity. Based upon similar observation for a large number of countries it is proposed that the 
nominal GDP growth rate can also be used as benchmark for the price of loans to/from the rest of the world including bilateral/multilateral and institutional arrangements. Pricing the international financial transactions in this manner can solve problems faced by countries in external debt management under Islamic finance principles. The paper also suggests central banks to use nominal income targeting. 


\section{References}

Chapra, Umer M. (1983), Monetary Policy in an Islamic Economy, Islamabad: Institute of Policy Studies.

Economist (2007), 'Closing the Valve,' The Economist, London, Print Edition, June 14.

Khan, Muhammad A. (1982), Inflation and the Islamic Economy: A Closed Economy Model, International Centre for Research in Islamic Economics, King Abdul Aziz University Press, Jeddah.

Khan, Muhammad A. (2004), 'Elimination of Interest: A Proposed Strategy,' Renaissance, Vol. 14 , Issue, 1.

Kurrihara, K. K. (1951), Monetary Theory and Public Policy, London.

Reddy, B. Muralidhar (2001), 'Of Religion and Economics,' Frontline, Vol. 18, No. 11.

Siddiqui, Muhammad N. (1982), Monetary Policy: A Review, International Centre for Research in Islamic Economics, King Abdul Aziz University Press, Jeddah.

Usmani, Muhammad T. (2003), Islam Aur Jadid Maeeshat-o-Tijaraht, Maktaba Mua'ariful Quran, Karachi.

Uzair, Mohammad (1982), 'Central Banking in an Interest-Free Banking System,' in Mohammad Arif (ed.) 'Monetary and Fiscal Economics of Islam,' International Centre for Research in Islamic Economics, Jeddah, pp. 211-235.

Zangeneh, Hamid and Salam, Ahmed (1993), 'Central banking in an Interest Free Banking System,' JKAU, Islamic Economics, Vol. 5, pp. 25-36. 


\section{Appendix}

Table 1: Results of the test of equality of means- Null Hypothesis: Means are equal:

\begin{tabular}{|l|l|l|l|l|l|l|l|}
\hline Country & \multicolumn{2}{|l|}{$\begin{array}{l}\text { Period of } \\
\text { Analysis }\end{array}$} & NGDGPR & OPINR & t-value & $p$-value & Results \\
\hline $\begin{array}{l}\text { Canada, } \\
\text { EU, Japan, } \\
\text { US \& UK }\end{array}$ & 1970 & 2008 & 7.53 & 7.51 & 0.02 & 0.98 & Not Rejected \\
\hline $\begin{array}{l}100 \\
\text { countries }\end{array}$ & 1981 & 2008 & 11.01 & 10.25 & 1.47 & 0.15 & Not Rejected \\
\hline Bahrain & 1986 & 2008 & 7.59 & 5.37 & 1.14 & 0.26 & Not Rejected \\
\hline Bangladesh & 1987 & 2008 & 10.32 & 7.10 & 4.51 & 0.00 & Rejected \\
\hline Egypt & 1977 & 2007 & 16.78 & 9.60 & 5.61 & 0.00 & Rejected \\
\hline Indonesia & 1990 & 2008 & 19.36 & 14.92 & 1.23 & 0.23 & Not Rejected \\
\hline Jordan & 1986 & 2007 & 8.56 & 7.01 & 1.33 & 0.20 & Not Rejected \\
\hline Kuwait & 1987 & 2008 & 12.39 & 6.23 & 1.16 & 0.26 & Not Rejected \\
\hline Malaysia & 1986 & 2008 & 10.48 & 4.76 & 4.33 & 0.00 & Rejected \\
\hline Oman & 1986 & 2007 & 7.51 & 6.59 & 0.41 & 0.69 & Not Rejected \\
\hline Pakistan & 1986 & 2008 & 14.54 & 11.67 & 2.17 & 0.04 & Rejected \\
\hline $\begin{array}{l}\text { Saudi } \\
\text { Arabia }\end{array}$ & 1987 & 2008 & 9.27 & 5.10 & 2.01 & 0.06 & Not Rejected \\
\hline Sudan & 1989 & 2006 & 57.21 & 51.33 & 0.36 & 0.72 & Not Rejected \\
\hline Yemen & 1996 & 2008 & 21.02 & 15.51 & 1.44 & 0.17 & Not Rejected \\
\hline
\end{tabular}


Table 2: List of 100 countries included in the average official interest rate and average nominal GDP growth rate:

\begin{tabular}{|c|c|c|c|c|c|}
\hline S. No. & Country & S. No. & Country & S. No. & Country \\
\hline 1 & Algeria & 35 & Fiji & 69 & Norway \\
\hline 2 & Anguilla & 36 & Finland & 70 & Oman \\
\hline 3 & Antigua \& Barbuda & 37 & France & 71 & Pakistan \\
\hline 4 & Aruba & 38 & Germany & 72 & Papua New Guinea \\
\hline 5 & Australia & 39 & Greece & 73 & Paraguay \\
\hline 6 & Austria & 40 & Grenada & 74 & Philippines \\
\hline 7 & Azerbaijan & 41 & Guinea-Bissau & 75 & Portugal \\
\hline 8 & Bahamas & 42 & Hungary & 76 & Qatar \\
\hline 9 & Bangladesh & 43 & Iceland & 77 & Rwanda \\
\hline 10 & Barbados & 44 & India & 78 & Senegal \\
\hline 11 & Belgium & 45 & Ireland & 79 & Seychelles \\
\hline 12 & Belize & 46 & Italy & 80 & Slovak Republic \\
\hline 13 & Benin & 47 & Japan & 81 & South Africa \\
\hline 14 & Botswana & 48 & Jordan & 82 & Spain \\
\hline 15 & Burkina Faso & 49 & Kenya & 83 & Sri Lanka \\
\hline 16 & Burundi & 50 & Korea & 84 & St Kitts \& Nevis \\
\hline 17 & Cameroon & 51 & Lesotho & 85 & St Lucia \\
\hline 18 & Canada & 52 & Libya & 86 & $\begin{array}{l}\text { St Vincent and the } \\
\text { Grenadines }\end{array}$ \\
\hline 19 & $\begin{array}{ll}\text { Central } & \text { African } \\
\text { Republic } & \\
\end{array}$ & 53 & Lithuania & 87 & Swaziland \\
\hline 20 & Chad & 54 & Malawi & 88 & Sweden \\
\hline 21 & China, PR: Hong Kong & 55 & Malaysia & 89 & Switzerland \\
\hline 22 & China, PR: Mainland & 56 & Maldives & 90 & Syria \\
\hline 23 & Colombia & 57 & Mali & 91 & Tanzania \\
\hline 24 & Congo & 58 & Malta & 92 & Thailand \\
\hline 25 & Costa Rica & 59 & Mauritania & 93 & Togo \\
\hline 26 & Côte d'Ivoire & 60 & Mauritius & 94 & Trinidad and Tobago \\
\hline 27 & Croatia & 61 & Montserrat & 95 & Tunisia \\
\hline 28 & Cyprus & 62 & Morocco & 96 & U.K \\
\hline 29 & Czech Republic & 63 & Myanmar & 97 & U.S \\
\hline 30 & Denmark & 64 & Namibia & 98 & Vanuatu \\
\hline 31 & Dominica & 65 & Nepal & 99 & Vietnam \\
\hline 32 & Ecuador & 66 & Netherlands & 100 & Yemen \\
\hline
\end{tabular}




\begin{tabular}{|l|l|l|l|l|l|}
33 & Egypt & 67 & New Zealand & & \\
\hline 34 & Ethiopia & 68 & Niger & & \\
\hline
\end{tabular}

